\title{
In vivo study of Rasa Bhasma on CCL4 induced Hepato-toxicity in Albino rats
}

\author{
Research Article
}

\section{Abhiram S P1*, Oorvi Kulkarni², Chinky Goyal ${ }^{3}$, Amrit Malik ${ }^{4}$}

\author{
1. Assistant Professor, Department of Agad Tantra, 2. Assistant Professor, Department of Kayachikitsa, \\ 3. Associate Professor and HOD, Department of Rasa Shastra \& Bhaishjya Kalpana, \\ 4. Associate Professor, Department of Agad Tantra, \\ Shri Dhanwantry Ayurvedic College and Hospital, Chandigarh. India.
}

\begin{abstract}
India stands 27 th in rank with $25.8 \%$ of death rate due to Liver diseases in 2016. In spite of scientific advancement in the field of Hepatology, Bio-medical science is clueless in finding out an effective drug against Hepatic Disorders. Detailed description on liver disorders and their management are given by all the three prominent Acharyas of Ayurveda. Rasa Bhasma is one such preparation that can be used to treat Hepatic Disorders. In present work an attempt has been made to evaluate the efficacy of Rasa Bhasma in the management of liver disorders. 24 animals were allocated into 4 groups having six animals in each group namely Group I (Normal/Control), Group II (Intoxicated Control) Toxicated Group, Group III (lower dose of Rasa Bhasma) and Group IV (Higher dose of Rasa Bhasma). All the four group were assessed for various biochemical Parameters viz. Alkaline phosphatase, SGOT (Serum glutamate oxalacetate transaminase)/AST, SGPT (Serum glutamate pyruvate transaminase)/ALT, Total Bilirubin, Direct Bilirubin and Total Proteins. Finally, the animals from all the four groups were sacrificed for Histopathological studies. The results were expressed as mean \pm SE and One way ANOVA by using statistical software SPSS version 16.0. Results revealed that the values of Group 4 are closer to the Normal Group1 than Group 3 meaning Rasa Bhasma in Higher dose is more effective than that in lower dose. Therefore, it can be concluded that Rasa Bhasma is a potent Herbo-mineral formulation for protection of hepatic cells.
\end{abstract}

Key Words: Rasa Bhasma, Hepato toxicity, Hepato-protectors.

\section{Introduction}

Liver is the vital organ of the human body involved in various functions viz. metabolism, secretion, storage and detoxification. In current scenario liver is the organ that is abused to the maximum extent. Under nutrition and Malnutrition are the other important causes of Liver damage especially in a developing country like India. Thus, it has become double burden for Liver as it has to perform not only the physiological function but also to protect itself against the hazards of harmful drugs and drug abuse. Liver cells gets damaged while protecting the body against various hazards which in turn leads to manifestation of liver diseases like Infective Hepatitis, Cirrhosis of liver, Toxic Hepatitis and Degenerative diseases of liver. In spite of scientific advancement in the field of Hepatology, Bio-medical science is clueless in finding out an effective drug against Hepatic Disorders. There are a number of medicines in Ayurvedic literature, which are scientifically proven to work as efficient Hepato-

\section{* Corresponding Author:}

\section{Abhiram S P}

Assistant Professor,

Department of Agad Tantra,

Shri Dhanwantry Ayurvedic College and Hospital,

Chandigarh. India.

Email Id: dr.abhiramsuri@gmail.com protectors. Despite the extra ordinary capacity of regeneration of this organ, slight injuries may lead to fatal complications.

Present day lifestyle changes are creating different kinds of health issues like Obesity, Arthritis, Digestive disorders and mainly Liver disorders. According to a survey conducted by W.H.O., alcohol consumption accounts for $3.8 \%$ of the global mortality and $4.6 \%$ of DALYs. Liver disease represents $9.5 \%$ of alcohol-related worldwide (1). The most important thing about Liver disorders is their asymptomatic nature in up to $50 \%$ of individuals. Main cause for Acute and Chronic Liver diseases is Alcohol consumption. The symptoms related to liver dysfunction include both physical signs and variety of symptoms related to digestive problems such as Loss of Appetite, Indigestion, Vomiting, etc. Bhasmas of various Metals and Minerals which are prepared using Parada are considered to be superior over Bhasmas prepared with Kashtoushadhis and Gandhakaadi dravyas. HerboMineral and Metallic drugs are often considered as effective for treating Chronic and Lifestyle related diseases. They also play a major role in the treatment of Hepatic Disorders. Rasa Bhasma (2) is one such preparation that can be used to treat Hepatic Disorders as Individual Ingredients of the same viz. Shuddha Parada, Apamarga and Bhringaraj are already proven to possess Hepato protective activity. So, in this present work an attempt has been made to evaluate and 
establish the Hepato protective action of Rasa Bhasma and its efficacy as a single medicine in the management of liver disorders.

\section{Materials and Methods}

\section{Procurement of Drugs and Formulation preparation}

Raw drugs having textual Grahya lakshanas were collected from the local market. Associate drugs used for the preparation viz., Apamarga and Bhringaraja were collected from Chebbi, Distt. Hubli Dhanwad, Karnataka. The test drug Rasa Bhasma was prepared as per the reference of Rasa Chintamani in the department of Rasa Shastra, Ayurveda Maha Vidyalaya, Hubli. Apamarga Kshara (3) was filled into the Sharava and a pit was made in the centre of which Shodhita Hingulottha Parada (4) was placed and Bhringaraja Swarasa was added. Shrava Samputa was done and Gorvara Puta was given in an Iron Vessel. After Swanga Shita, grey coloured Rasa Bhasma was collected and stored.

\section{Experimental animals and ethics committee approval}

24 Albino rats of either sex weighing between 150-250 gm were selected for the present study. They were housed individually in polypropylene cages in well-ventilated rooms. The rats were kept under observation for seven days with standard laboratory diet. After which they were examined for their normal health and then subjected to experimental study. The study was carried out after obtaining permission from Institutional Animal Ethics Committee with Approval number-112/PO/ReS/1999 and the guidelines of CPCSEA (Committee for the purpose of control and supervision of experiments on animals), Govt. of India, were strictly followed during the study. The experimental model suggested by Watanabe and Takita (1973) was adopted.

\section{Experimental design}

24 animals were randomly allocated into 4 groups having six animals in each group namely Group I (Normal/Control), Group II (Intoxicated Control Liver Damage) Toxicated Group, Group III (Curative Group treated with lower dose of Rasa Bhasma) and Group IV (Curative Group treated with Higher dose of Rasa Bhasma). Human dose of Bhasma is 1 Ratti /day (Minimum dose) and 2 Ratti/day (Maximum dose)converted into rat dose by using the formula $0.018 \times$ human dose =rat dose i.e, $0.018 \times 125=$ $2.25 \mathrm{mg}(0.4 \mathrm{ml}), 0.018 \times 250=4.5 \mathrm{mg}(0.8 \mathrm{ml})$. Rasa Bhasma was given in the form of aqueous suspension. 2 gm of Rasa Bhasma was added to $40 \mathrm{ml}$ of $2 \%$ twin 20 (suspending agent) solution and mixed well. Each 0.4 and $0.8 \mathrm{ml}$ contains $2.25 \mathrm{mg}$ and $4.5 \mathrm{mg}$ of Rasa Bhasma.

Table no 1 showing Experimental Protocol

\begin{tabular}{|c|c|c|c|}
\hline Group & Pre-treatment dose/route & Duration of Treatment (days) & Day of withdrawal of blood \\
\hline Group 1 & Vehicle & $1-7$ & $16^{\text {th }}$ \\
\hline Group 2 & $\mathrm{CCL}_{4} 0.7 \mathrm{ml} / \mathrm{kg}$, i.p & $1-7$ & $16^{\text {th }}$ \\
\hline Group 3 & $\mathrm{CCL}_{4} 0.7 \mathrm{ml} / \mathrm{kg}$, i.p & $1-7$ & $16^{\text {th }}$ \\
\cline { 2 - 4 } & RASA BHASMA $2.25 \mathrm{MG} / \mathrm{KG}$, ORALLY & $8-15$ & $16^{\text {th }}$ \\
\hline \multirow{2}{*}{ Group 4 } & $\mathrm{CCL}_{4} 0.7 \mathrm{ml} / \mathrm{kg}$, i.p & $1-7$ & \\
& RASA BHASMA $4.5 \mathrm{MG} / \mathrm{KG}$, ORALLY & $8-15$ &
\end{tabular}

All the four group animals were assessed on $16^{\text {th }}$ day using an auto-analyzer for various biochemical Parameters viz. Alkaline phosphatase, SGOT (Serum glutamate oxalacetate transaminase)/AST, SGPT (Serum glutamate pyruvate transaminase)/ALT, Total Bilirubin, Direct Bilirubin and Total Proteins. Finally, the animals were sacrificed on the day of blood withdrawal from all the five groups for Histo-pathological studies.

\section{Statistical analysis}

The results were expressed as mean \pm SE by using statistical software SPSS version 16.0. All statistical comparisons between the groups were made by means of One Way ANOVA (Analysis of Variance). The $p$ value $<$ 0.05 was regarded as statistically significant and $<0.01,<0.001$ were taken as statistically highly significant.

\section{Results}

Table 2: Showing biochemical values of all groups

\begin{tabular}{|c|c|c|c|c|c|c|}
\hline Group & AST (U/d) & ALT(U/d) & ALP(U/d) & $\begin{array}{c}\text { Direct } \\
\text { 'Bilirubin (mg } \\
\text { /dl) }\end{array}$ & $\begin{array}{c}\text { Total } \\
\text { Bilirubin } \\
\text { (mg /dl) }\end{array}$ & $\begin{array}{c}\text { Total Protein } \\
\text { (mg /dl) }\end{array}$ \\
\hline Group 1 & $55.65 \pm 0.78$ & $48.24 \pm 21.01$ & $210.2 \pm 18.5$ & $0.71 \pm 0.01$ & $0.31 \pm .02$ & $10.2 \pm 0.04$ \\
\hline Group 2 & $144.5 \pm 1.58$ & $138.7 \pm 1.57$ & $527.2 \pm 16.5$ & $3.5 \pm 0.02$ & $2.7 \pm .04$ & $14.1 \pm 0.02$ \\
\hline Group 3 & $69.52 \pm 2.5$ & $65.32 \pm 0.02$ & $110.47 \pm 0.04$ & $0.5 \pm 0.01$ & $0.2 \pm 0.01$ & $6.5 \pm 0.04$ \\
\hline Group 4 & $77.46 \pm 0.45$ & $83.21 \pm 15.68$ & $105.40 \pm 0.65$ & $0.30 \pm 0.06$ & $0.15 \pm 0.03$ & $6.45 \pm 0.43$ \\
\hline
\end{tabular}




\section{Graph No. 1: Mean AST of all the groups}

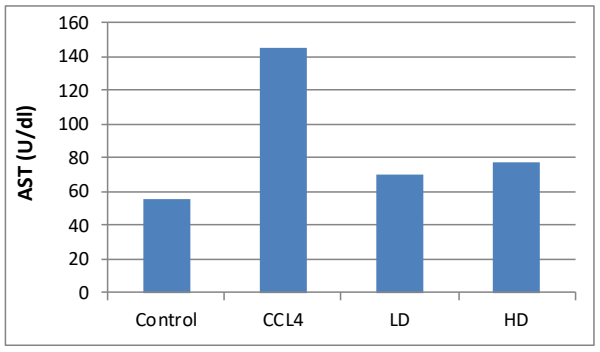

Graph No. 4: Mean Direct Bilirubin of all groups

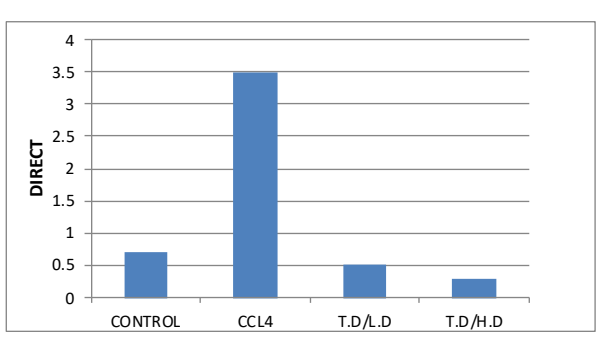

Graph No 2: Mean ALT of all the groups

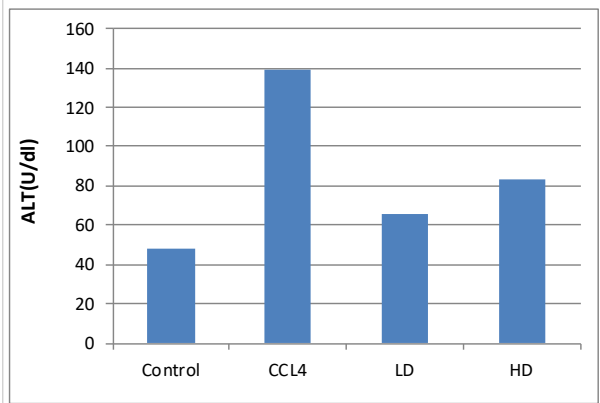

Graph No. 5: Mean Total Bilirubin of all groups

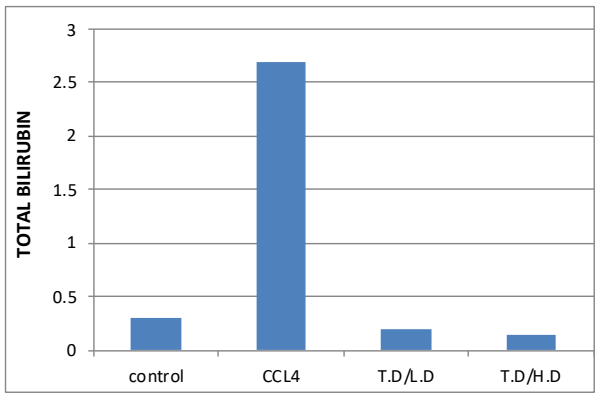

Graph No. 3: Mean ALP of all the groups

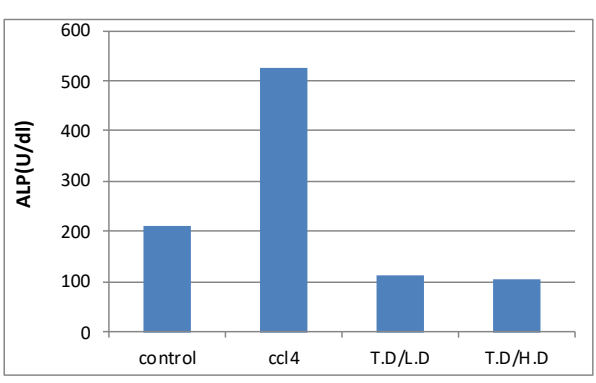

\section{Discussion}

Dose of Rasa Bhasma has been chosen as per Rasa Tarangini, (5) it being the recent text of Rasashastra, where doses are mentioned according to the tolerance of newer generation.

In group 2 all the biochemical values SGPT, SGOT, ALP, T-Bil, and Albumin were highly increased except the serum albumin which is decreased. The histopathology study of Liver of this group showed severe degree necrosis, ballooning degeneration, and broad infiltration of the lymphocytes and kupffer cells around the central vein and the loss of cellular boundaries. It indicates that in course of $\mathrm{CCl}_{4}$ administration leads to functional defects of the hepatocytes \& multiple biochemicals took place.

Biochemical \& histopathological observations shown that these two trial drugs significantly efficient in protecting the liver.Except Higher dose of RASA BHASMA in case of SGOT and SGPT. Liver is an organ which is made up of soft tissues. Any damage which was caused to parenchymal tissue of this organ is reflected in certain parameters like S.G.O.T. \& S.G.P.T., which will show a significant increase in their levels. In this experimental study, there was rise of S.G.O.T. \& S.G.P.T., in $\mathrm{CCL}_{4}$ induced group (G2) which was Hepato-toxic induced group. Group 3 and Group 4 values have been decreased after treated with $R A S A$ BHASMA in two divided doses. Whereas when compared to Group3, there is a slight difference in values of S.G.O.T. \& S.G.P.T., which might have happened because of tissue damage which has occurred during inducing Hepato-toxicity.

To reveal the curative effect of treated groups (G3 \& G4), Bio chemical values and Histo pathological study of Liver were analysed.

\section{Histopathology study photographs}

Figure 1: Pictomicrograph Figure 2: Pictomicrograph of Normal healthy liver (Group 1)

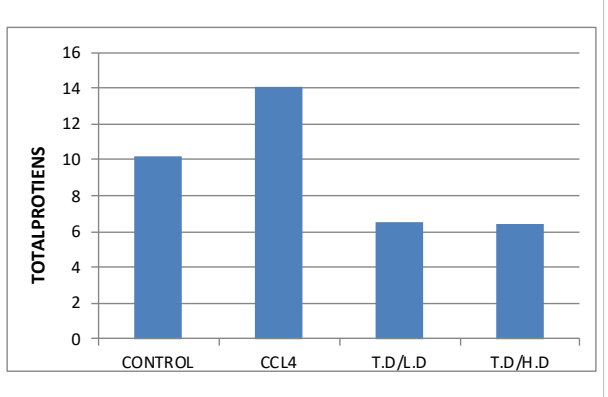

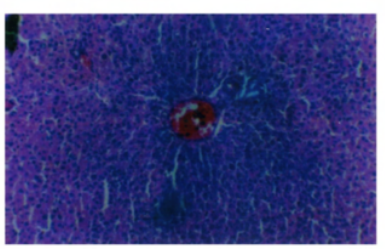

Figure 3: Pictomicrograph of liver treated with rasa bhasma in lower dose (Group 3)

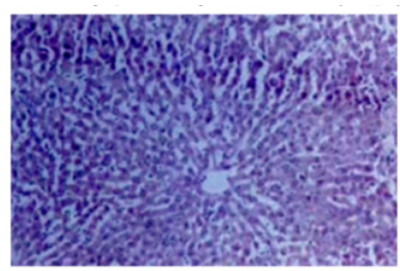
of Damaged liver with $\mathrm{CCL}_{4}$ (Group 1)

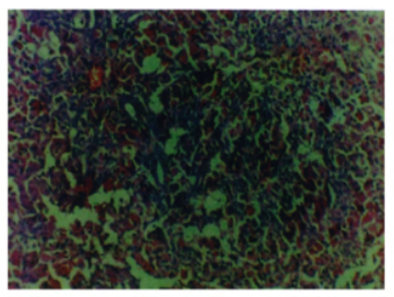

Figure 4: Pictomicrograph of live treated with Rasa Bhasma inhigher dose (Group 4)

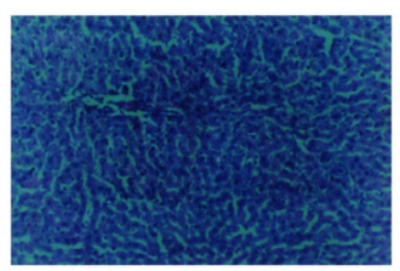

Group 2 with Group 3 showed significant difference. Group $\mathbf{2}$ with Group $\mathbf{4}$ also showed significant difference with all Biochemical values. It indicates that RASA BHASMA when given in two divided doses, have significant effect in protecting liver. The Histopathology of Group 3 showed central vein surrounded by hepatocytes with sinusoidal dilatation with occasional inflammatory cells. No hepatic necrosis was seen around central vein or in the Central zone. Histopathology of Group 4 showed well brought out 
central vein, hepatic cell with well-preserved cytoplasm, prominent nucleus and nucleolus.

But when we compare all other investigation values and Histo-pathology studies of all the other groups, and when analysed, we came to know that the effect is not equal and Biochemical observations reveal that the values of Group 4 are closer to the Normal Group1 than Group 3. So Rasa Bhasma in Higher dose is more effective than that in lower dose.

\section{Conclusion}

The drugs used to prepare Rasa Bhasma in the present study i.e, Apamarga Kshara, Bhringaraja and even Paarada has got protective action on Hepatic cells combined with its yogavahi property, which is evident from the findings of the present study. On observing the Experimental study data and its statistical analysis, it can be concluded that Rasa Bhasma is found to be a potent Herbo-mineral formulation for protection of hepatic cells.

\section{Reference}

1. Garg V, Garg H, Khan A, Trehanpati N, Kumar A, Sharma BC, Sakhuja P, Sarin SK Granulocyte colony-stimulating factor mobilizes CD34+ cells and improves survival of patients with acute-onchronic liver failure. Gastroenterology 2012; 142: 505-512.

2. Acharya Anantadev Soori, Rasa Chintamani with Siddhi prada hindi commentary by Siddhinandan Mishra, Third editon: 2008 publised by Chaukamba Publishers, Varanasi.

3. Acharya Sarangadhara, Sarangadhara Samhita, Bramhananda Tripathi, $1^{\text {st }}$ Edition, Varanasi, Chaukhamba Surbharati Prakashan, 2020 Chapter No 11 Sloka 102-104, Page no. 185

4. Sri Vagbhatacharya, Rasaratna Samucchaya, Indradeva Tripati, 1st Edition, Varanasi, Chaukhambha Sanskrit Sanstan, 1998, Chapter No 3, Sloka No 154, Page No 41.

5. Sri Sadanand Sharma, Rasatarangini, Editor Kashinath Shastri, 11th Edition, Varanasi, Motilal Banarasi Dass, 2004, Chapter No 9, Sloka No 1-2, Page No 198. 